\title{
FOREIGN EXPERIENCE OF LEGAL PROTECTION OF POLICE OFFICERS AND PROSPECTS OF ITS USE IN UKRAINE
}

\author{
Mykola Veselov ${ }^{1}$, Daria Volkova ${ }^{2}$ \\ ${ }^{I}$ Doctor of Law, Associate Professor, Associate Professor of the Department of Criminal Law, Kryvyi Rih \\ Faculty, National University "Odesa Law Academy”, Kryvyi Rih - Odesa, Ukraine, e-mail: \\ veselovndl@ukr.net, ORCID: https://orcid.org/0000-0002-3963-2764 \\ ${ }^{2}$ Applicant of the Kryvyi Rih Faculty of the National University "Odesa Law Academy", Kryvyi Rih - Odesa, \\ Ukraine, e-mail: truehomoo@gmail.com, ORCID: https://orcid.org/0000-0002-5131-8305
}

\begin{abstract}
Today, the protection of police officers is one of the important conditions for the effective operation of the National Police as a whole. The object of this study is public relations in the specific field of ensuring the safety of life and health of police officers from unlawful encroachments related to the performance of their professional duties. The purpose of the article is to clarify the features of legal protection of police officers in the performance of their official duties in other countries and outline possible ways to improve this activity in Ukraine. To achieve this goal, general scientific and special methods of scientific research were used. The state and level of legal regulation of police protection in other countries of the world emphasizes the importance of this issue to ensure their rights, as well as the effectiveness of the police in general. It has been established that the protection of police officers in the performance of their official duties is carried out by a number of organizational, logistical and legal measures, which are enshrined in the norms of administrative and criminal law. As a result, the expediency of expanding in the legislation of Ukraine some powers of police officers, which will affect their own safety and guarantee the safety of others, is substantiated. In addition, it is proposed to establish administrative liability for insulting or disrespecting a police officer in the performance of his duties, as well as for slandering a police officer in order to discredit him, imposing severe sanctions for these offenses.
\end{abstract}

Keywords: foreign experience, police, policeman, protection of police officers, performance of official duties, personal safety.

JEL Classification: K14, K23, K42

Formulas: 0; fig.: 0; tabl.: 0; bibl.: 16

Introduction. The Constitution of Ukraine (Art. 3) states that a person, his life and health, honor and dignity, inviolability and security are recognized as the highest social value [1]. The issues of creating effective guarantees of safe living of those persons on whom the law entrusts the implementation of law enforcement functions due to their state professional activities are of particular importance in the development of any democratic state. The effective operation of government bodies and civil society institutions is a guarantee of respect for the rights and interests of citizens, the successful solution of the challenges facing the state and society. By empowering the authorities, the state, on the one hand, places high demands on them and, on the other hand, provides them with enhanced protection so that they can perform their functions without hindrance, without any outside influence, and, in making decisions,they can be convinced of the safety of their own lives, health, property, as well as the safety of life, health, other rights and interests of their loved ones. In this study, we intend to focus on the specifics of police legal protection.

Literature review. Issues related to the legal regulation of security of law enforcement agencies were considered in the works of M. Vitruk, B. Gabrichidze, V. Yevintov, R. Kalyuzhnyi, V. Kolisnyk, O. Koristin, X. Lauterpakht, S. Lysenkov, R. Muellerson, O. Negodchenko, A. Oliynyk, L. Rozin, D. Sebain, S. Slyvka, 
S. Starzhynskyi, Ye. Starostsiak, K. Tolkachov, T. Thorson, Y. Troshkin, A. Khabibulin, O. Shmotkin and others. At the same time, the analysis of statistical data and some specific cases of illegal influence on law enforcement officers, in particular police officers in connection with their professional duties, shows that recently this trend has become a large-scale socio-legal problem affecting vital interests of the individual, society and the state, and it poses a threat to national security.

Aims. The aim of this article is to clarify the features of the legal protection of police officers in the performance of their duties in other countries and outline possible ways to improve this activity in Ukraine.

Methods. To achieve this goal, general scientific and special methods are used, which are tools of scientific research (structural-functional and systemic, formallogical, hermeneutic, etc.).

Results. Today, the study and effective use of the experience of developed foreign countries to ensure the safety of law enforcement officers, including police, is of great theoretical and practical importance. Interest in the prospects of legal protection of personnel in the domestic law enforcement system is especially growing. In addition, expanding the process of integration of the Ukrainian police into the international community of law enforcement agencies requires more detailed acquaintance with the theory and practice of organizing various aspects of foreign police activities, including in protecting their police personnel from unlawful encroachments. The analysis of the scientific literature on this issue allows us to identify several aspects related to the professional activities of police officers, their relationships with the public and offenders, as well as legal measures, which are relevant and effective at this time to protect law enforcement officers.

Legal protection of police officers in most foreign countries actually begins from the moment they are hired. A police officer or gendarme, regardless of where he is hired, is considered to be endowed with certain powers guaranteed by the state [2, p. 20]. National laws and legislations of different countries regulate the situation of police officers. At the same time, police officers occupy a specific place among other civil servants, that is due to the nature of the functions assigned to the police. In different countries, the system of norms regulating the organization of service in police structures and the legal status of their staff, are contained mainly in national laws "On Police", decrees and edicts of heads of states and executive, legal acts of local governments, which include provisions on the legal regime certain categories of law enforcement officers. All such documents include directives that police personnel form a special category in the public service and have the appropriate status [3, p. 28].

Legal protection of police and gendarmerie in France is reliably provided by the legislation of this country. According to the French Criminal Code (adopted on July 22,1992 ), police and gendarmes (as well as all civil servants) are specially protected from unlawful encroachments, threats, insults or slander to which they may be subjected. Article 221-4 (part 4) of the French Criminal Code provides for the life imprisonment (the death penalty in France is abolished) of a person who has 
committed the premeditated murder of a police officer or gendarme. Violent acts against them, if they caused death, without intent to kill, are punishable by 20 years in prison (Art. 222-8 part 4), and the same actions, if they caused disability "for more than 8 days", are punishable five years' imprisonment and a fine of up to $€ 100,000$ (art. 222-12) [4, p. 150-151]. For verbal abuse of French law enforcement officials in the performance of their duties, the perpetrators are punishable by arrest for a term of fifteen days to three months or a fine. The perpetrator may be sentenced to up to five years in prison for using physical force or committing another act of aggression against a police officer. Relevant, in the context of police protection, is Article 431-3 of the French Criminal Code, which defines the conditions and grounds for the use of physical force, special means and weapons by police without warning: if violent acts are directed against law enforcement officials; as well as when law enforcement agencies are unable to otherwise protect the territory they occupy [5].

In addition to criminal law protection, special attention should also be paid to the mechanisms of public support and protection of police rights, to security in connection with their professional activities. There are about thirty trade unions in France to protect the police. A typical example is the activity of the French police union "Alliance", which constantly demands from the leadership of the Ministry of Internal Affairs security guarantees, staffing and additional measures that would allow police officers serving in troubled suburban areas of Paris to stop armed attacks by youth street groups. The above allows us to conclude about the unconditional importance of detailed legal regulations for the protection of police and gendarmes in France in the performance of their law enforcement functions.

Another foreign example of the organization of legal protection of police officers can be the experience of Estonia (one of the former Soviet republics). The armed police of this country have various special measures: rubber truncheons, handcuffs, other special means, service dogs, means of forced stopping of vehicles, etc. The use of weapons and special means is allowed in order to stop a socially dangerous act that threatens the life and health of citizens, detain those who committed such acts and bring them to the police. When deciding on the possibility and necessity of using a weapon or special means, a police officer must take into account the existence of the offense and its legal nature, the identity of the offender, the general situation of the offense. In Estonia, restrictions on the use of physical force and weapons by police are clearly defined [6, p. 132].

In general, we can say that the experience of reforming the law enforcement system in Estonia is quite positive. One of the important principles of police reform in this country was the principles of public confidence in policing (or so-called "community policing") and openness, which changed the attitude towards the police in general and the police in particular, minimized police interference in public life and the population's respect for the police increased [6, p. 176], which certainly affects the minimization of negative encroachments on the safety of police officers in the performance of their duties by others.

In the vast majority of US states, assaulting or physically resisting police officers is punishable by a fine of five to ten thousand dollars and (or) imprisonment 
for a term of three to ten years [3, p. 28-29]. In the United States, you can't argue with the police, let alone insult a police officer in the line of duty - you can go to jail for disrespecting a law enforcement official. In addition, the American police officer has every opportunity to ensure his own safety. According to the current rules, he can use a firearm in any situation that he considers dangerous to his life and health.

Austrian law provides for a special and, it should be noted, rather strict legal protection of police officers in the performance of their duties from slander and insult. According to the provisions of $\S 111,115$ of the Austrian Criminal Code, they, as part of civil servants, have a special procedure for protection against threats, insults and slander. Defamation under $\S 111$ of the Austrian Criminal Code is punishable by up to six months' imprisonment or a fine of up to 360 daily rates (approximately 31.8 thousand euros). The same act committed with the use of the media or other public means is punishable by imprisonment for up to one year or a fine of up to 360 daily rates. Insult under $\S 115$ of the Austrian Criminal Code is punishable by imprisonment for up to three months or a fine of up to 180 daily rates.

In Austria in particular, the law also protects police officers from violence or threats of violence against them, which hinders their policing. According to $\S 269$ of the Austrian Criminal Code, such acts are punishable by imprisonment for up to three years, and in case of illegal coercion of a police officer to act (inaction) against the public interest is punishable for six months to five years [7, p. 111].

In almost all developed countries, the law provides for strict liability for insulting, counteracting or causing physical harm to or slandering police officers. In England, if an offender argues with a police officer, he may be charged with disobedience to the police, which carries a prison sentence of up to two months for such a person. In Italy, insulting police officers in a public place or through the media is punishable by up to three years in prison. In Germany, for spreading slander against the executive (including the police), aggression against their representatives is punishable by up to five years in prison or a large fine.

In foreign countries, national professional police associations have a certain identity. Thus, in the United Kingdom there is the Police Federation of England and Wales (PFEW - an association of police constables, sergeants and inspectors, including chief inspectors, is one of the largest staff associations in the UK representing more than 130,000 rank and file officers) [8], The Police Federation of Scotland (SPF represents all police officers and numbers more than 18,500 people, representing 98\% of all Scottish police) [9], the Police Federation of Northern Ireland [10]. All police officers who have a police rank from constable to superintendent become members of the British Police Federation after enlistment.

There is an axiom all over the Western world: a policeman is inviolable, even if you personally think he is wrong. We have all seen how the police work in the United States, where even for refusing to comply with the requirements of a police officer you can get a bullet, not to mention an attack on a police officer. Thus, the protection of police personnel is the basis of law and order in any civilized country. An attack on a police officer is not only an illegal act against a person, but an attack on a person to whom the state has entrusted the protection of other citizens and public interests in 
general. The danger of such offenses is that they undermine the constitutional foundations of the state and the functioning of its institutions.

It should be noted that in the West, society as a whole shares the need to expand the rights of law enforcement. According to a poll conducted in Western Europe, as well as in the United States, Canada and Japan (Law and Order), citizens are convinced that the expansion of police competence is necessary, even if it is contrary to the principles of democracy. More than $60 \%$ of respondents believe that the police have the right to act harshly if law enforcement officers consider it necessary and if it ensures the safety of citizens and police officers [5]. In Ukraine, this issue is not so clear-cut. Thus, in 2016, after the tragic shooting of police officers in Dnipro (during the detention of a criminal), the desire of the Ministry of Internal Affairs of Ukraine to introduce in our country (by amending the Law of Ukraine "On National Police") "presumption of police" had public outcry. However, this desire of law enforcement officers caused a lot of objections from human rights activists and the community in general. The basis for criticizing the proposals of the Ministry of Internal Affairs of Ukraine was unfounded doubts about the readiness of Ukrainian police to expand their competence. However, in our opinion, the powers of law enforcement officers in some situations that arise during the provision of police services, in order to ensure the own safety of police officers, really need to be expanded. In particular, this applies, for example, to the permissibility (legality) of forcible removal of the driver and (or) other persons from the interior of the vehicle by breaking the glass of the car, if the actions of such persons pose a threat to the safety of police officers or others. Until now, in our country, this issue does not have proper legal regulation.

Discussion. In Ukraine, the problem of democratization and transformation of law enforcement agencies into law enforcement services and their proximity to the population, in the process of reforming the system came into the sphere of scientific interests of many scientists. In particular, it is considered by O. Okopnyk [11], O. Bandurka [12], but only in the perspective of establishing interaction between law enforcement agencies and the public, finding all possible forms and methods of public involvement to assist in law enforcement tasks, including security as citizens and the personal safety of police officers. However, the narrow vision of the problem limits the possibilities of its solution, as nothing will help bring the police closer to the population than cooperation to increase security in the form of service and public function, which will provide opportunities for both citizens and legal entities, realization of their rights, responsibilities and legitimate interests [13, p. 7].

As it turned out, one of the forms of legal guarantees for the activities of police officers is the consolidation of legal liability for offenses against such persons in the performance of their duties. In particular, the legislation of Ukraine contains provisions on such liability in the norms of civil, administrative tort and criminal law.

Thus, Art. 185 of the Code of Ukraine on Administrative Offenses provides responsibility for malicious disobedience to the lawful order or requirement of the police officer. Art. 185-7 of the Code of Administrative Offenses provides responsibility for public appeals to non-compliance with the requirements of a police officer or dissemination of knowingly false information in order to provoke 
disobedience to a lawful request of a police officer, provided that these actions have led to a violation of public order. In turn, criminal liability may occur in case of resistance (part 2 of Art. 342 of the Criminal Code of Ukraine), threat or violence (Art. 345 of the Criminal Code of Ukraine), intentional destruction or damage to property (Art. 347 of the Criminal Code of Ukraine), encroachment on life ( which includes murder or attempted murder) (Art. 348 of the Criminal Code of Ukraine) of law enforcement officers in the performance of their duties. However, it should be noted that the mere establishment of one or another type of legal liability in the law for counteracting a police officer does not make the latter's activities guaranteed and safe. Analysis of law enforcement practice, on the example of prosecution under Art. 185-7of the Code of Ukraine on Administrative Offenses, indicates rather rare cases of use of this norm. I. Senchuk believes that the main reason for this is extremely insignificant sanctions or rather broad alternative types of penalties or punishments. Thus, malicious disobedience to a police officer entails the imposition of a fine of 8 to 15 non-taxable minimum incomes or community service for a period of 40 to 60 hours, or correctional labor for a period of one to two months with deduction of $20 \%$ of earnings, or administrative arrest for a period up to 15 days. Courts, as a rule, impose fines, which today is only from 136 to $255 \mathrm{UAH}$. Arrest is practically not used [14, p.90]. In addition, acts of individuals, such as insult, contempt for the police or desecration of the police uniform (in the performance of official duties), which certainly have a negative impact on law enforcement, the authority and image of the police as public authority, but have no grounds for appropriate legal response (do not provide for the necessary legal liability in such cases). Defamation or spreading unfounded rumors about a police officer can only result in civil liability, provided that a civil lawsuit is filed by the latter, that in fact transfers such legal relations from the category of public to private.

Thus, it should be noted that the legal guarantees of police activity today are mostly declarative in nature. They do not achieve the main goal - general prevention. It is sad to admit, but now Ukrainian law does not provide for any effective measures against the "offender" in response to insults to the police. But in 2017, this bill was withdrawn. At the same time, as we have pointed out in previous publications, administrative tort of illegal acts allows authorized state bodies not only to respond to such facts, but also to identify the causes and conditions of their occurrence, in order to prevent in a timely manner [16, p. 55].

Conclusions. Given the above, we can draw the following conclusions.

First, the analyzed experience of legal regulation of police protection in other countries of the world once again emphasizes the importance of this issue for ensuring their rights, as well as the effectiveness of the functioning of police bodies in general.

Secondly, the protection of police officers in the performance of their duties is carried out by a number of measures of organizational, logistical and legal nature, which is enshrined in the rules of administrative and criminal law.

Thirdly, today in Ukraine it is expedient to expand the powers of police officers in the legislation, which will affect their own safety and ensure the safety of others. 
This applies to the admissibility (legality) of forcible removal of the driver and (or) other persons from the interior of the vehicle by breaking the glass of the car, if the actions of such persons pose a threat to the safety of police or others, and they refuse to comply with legal requirements. Currently, this issue does not have proper legal regulation.

Fourth, in order to create an effective and consistent system of protection of police rights, maintaining the authority and security of the police in our country as a whole from possible negative manifestations that interfere with police activities, it is necessary to establish administrative liability for such acts as insult or disrespect to the police in the performance of official duties, as well as defamation of a police officer in order to discredit him, imposing severe sanctions for these offenses.

Today, this sphere of public relations is not without a number of problems that need scientific and legal solutions. At the same time, blind copying of foreign experience may not always be expedient, because the legal basis and social conditions of police service abroad differ from the activities of domestic "law enforcement officers". Based on this, the outlined areas (taking into account the positive developments of international experience) create prospects for further indepth study of police protection in Ukraine and the possible introduction of the necessary changes to Ukrainian legislation.

\section{References:}

1. Constitution of Ukraine. (1996). Law of Ukraine of June 28, 1996 No. 254k/96-VR. Date of update: 01.01.2020. URL: https://zakon.rada.gov.ua/laws/main/254\%D0\%BA/96-\%D0\%B2\%D1\%80. [in Ukrainian].

2. Gudkov, A.Ju. (2011). Zashhita policejskih za rubezhem. "Protection of police officers abroad". Bulletin of the Omsk Law Institute, No 4 (17): 20-23. [in Russian].

3. Shevchenko, I.A., Bezhencev, A.A. (2018). Obespechenie sluzhebnoj dejatel'nosti sotrudnikov organov vnutrennih del: polozhitel'nyj zarubezhnyj opyt i perspektivy ego ispol'zovanija v Rossii. "Ensuring the service activities of law enforcement officers: positive foreign experience and prospects for its use in Russia". Law and law, No 2: 24-30. [in Russian].

4. Bykov, A.V., Kikot'-Gluhodedova, T.V. (2015). Policejskaja sistema sovremennogo demokraticheskogo gosudarstva. "The police system of a modern democratic state". Moskva: Juniti, 303. [in Russian].

5. Klen'ko, L. (2019). Massovye besporjadki i policija: vopros bezopasnosti. "Mass riots and the police: a security issue". Russian agency of legal and judicial information. URL: http://rapsinews.ru/legislation_publication/20190329/297022044.html. [in Russian].

6. Filshtein, M.V. (2016). Politseiski orhany Prybaltiiskykh derzhav-chleniv Yevropeiskoho Soiuzu (Latviia, Lytva, Estoniia): orhanizatsiia ta pravove zabezpechennia diialnosti v sferi vnutrishnikh sprav. "Police authorities of the Baltic States-members of the European Union (Latvia, Lithuania, Estonia): organization and legal support of activities in the field of internal affairs". Candidate's thesis. Kyiv, 228. [in Ukrainian].

7. Krylova, N.E. (Ed.). (2001). Ugolovnyj kodeks Avstrii. "Austrian Criminal Code". Moscow, 133. [in Russian].

8. Police Federation of England and Wales. (n. d.). About us. URL: https://www.polfed.org/about-us/.

9. Scottish Police Federation. (n. d.). What we are. Structure of the Organisation. URL: https://spf.org.uk/about/what-we-are/.

10. Police Federation Northern Ireland. (n. d.). What We Do. URL: https://www.policefed-ni.org.uk/about.

11. Okopnyk, O.M. (2007). Orhany vnutrishnikh sprav v orhanizatsiino-pravovomu mekhanizmi realizatsii vykonavchoi vlady v Ukraini. "Units of internal affairs in the organizational and legal mechanism of realization of executive power in Ukraine". Candidate's thesis. Kharkiv, 179. [in Ukrainian].

12. Bandurka, O.M., Dzhafarova, O.V. (2004). Militsiia i naselennia: Teoriia i dosvid partnerstva. "Police and population: Theory and experience of partnership". Kharkiv: Publishing House of the National University of Internal Affairs, 199. [in Ukrainian]. 
13. Subbot, A. (2014). Zastosuvannia v Ukraini peredovykh svitovykh standartiv orhanizatsii efektyvnoi diialnosti pravookhoronnykh orhaniv. "Application of advanced world standards for the organization of efficient operations of law enforcement agencies in Ukraine". Viche, No 10: 5-8. [in Ukrainian].

14. Senchuk, I.I. (2018). Harantii profesiinoi diialnosti politseiskykh v suchasnykh umovakh. "Guarantees of professional activity of policemen in modern conditions". Forum Prava, No 3: 88-95. DOI: http://doi.org/10.5281/zenodo.1405638. [in Ukrainian].

15. Verkhovna Rada of Ukraine: Official webportal. (2016). Pro vnesennia zmin do deiakykh zakonodavchykh aktiv Ukrainy (shchodo posylennia vidpovidalnosti za pravoporushennia, uchyneni vidnosno pratsivnykiv pravookhoronnykh orhaniv). "On Amendments to Certain Legislative Acts of Ukraine (Regarding Strengthening Liability for Offenses Committed Against Law Enforcement Officials)". Draft Law of Sept. 9, 2016 No 5110. URL: http://w1.c1.rada.gov.ua/pls/zweb2/webproc4 1?pf3511=60000. [in Ukrainian].

16. Veselov, M. (2020). Administrative and legal ensure of "the best interests of the child" in the field of junior justice. Public Administration and Law Review, Issue 3: 49-56. DOI: https://doi.org/10.36690/26745216-2020-3-49. 